\title{
Health and economic growth among the states of Brazil from 1991 to 2000
}

\author{
Kenya Noronha* \\ Lízia de Figueiredo** \\ Mônica Viegas Andrade ${ }^{\star * *}$
}

\begin{abstract}
Health status can affect economic growth through at least three mechanisms: 1) directly, through the relationship between health status and individual earnings, 2) indirectly, through the effect of health on levels of education, and 3) through physical capital investments. Poor health status causes considerable losses in individual income by decreasing labor productivity, numbers of hours worked, and participation in the labor force. These losses can affect a population's level of wealth and contribute to decreased social well-being. The main goal of this study is to assess the relationship between health and economic growth among the Brazilian states between 1991 and 2000. In order to take into account the different epidemiological and morbidity profiles observed among the states, several health measures were selected such as infant mortality rate, hospital mortality rate in the public healthcare system due to perinatal complications, and proportion of deaths from selected causes (vascular diseases, diabetes, cancer, AIDS and other communicable diseases, homicides and ill-defined causes). Our main findings show that in Brazil health correlates positively with economic growth. We also found that decreases in infant mortality rates are closely associated with higher rates of economic growth. We found a significant negative relationship for health indicators that are related to poverty, less access to health care services and deaths from avoidable causes, such as communicable diseases and hospital mortality rates due to perinatal complications. In contrast, we found a positive and significant correlation between the proportion of deaths from diabetes and cancer, on the one hand, and economic growth, on the other.
\end{abstract}

Keywords: Health. Economic growth. Human capital.

\section{Introduction}

In recent decades, Brazil has undergone changes in its demographic structure due to lower fertility rates and, to a lesser extent, to lower mortality rates, and these factors have contributed to the accelerated aging process in the country. Between 1950 and 2005 the percentage of individuals aged 60 or older increased from $5 \%$ to $9 \%$ of the total population and, according to projections, this percentage will reach $25 \%$ by 2050 (UNITED NATIONS 2007). As a result, changes have occurred in the morbidity and mortality profile

\footnotetext{
* Ph.D in Economics, Department of Economics Cedeplar/UFMG, associate professor, Department of Economics, Cedeplar/UFMG.

${ }^{* *}$ Ph.D in Economics, University of Nottingham, associate professor, Department of Economics, Cedeplar/UFMG.

${ }^{* * *}$ Ph.D in Economics, EPGE - Fundação Getúlio Vargas, associate professor, Department of Economics, Cedeplar/UFMG.
} 
of the Brazilian population, such as increased prevalence of chronic illnesses and a lower prevalence of communicable diseases (IDB 2005). This process occurred unevenly across Brazilian regions because of their different epidemiological profiles.

The main goal of this study is to assess the relationship between health and economic growth among the Brazilian states between 1991 and 2000. Only recently, specifically since the 1990s, has health been considered a possible determinant for economic growth. Its inclusion as a component of human capital was first suggested by Mankiw, Romer and Weil (1992). Two main difficulties can at least in part explain the recent inclusion of health as a determinant of economic growth: 1) the possible existence of endogeneity between health and wealth and, 2) the difficulties involved in finding comparable health indicators among countries that measure the multiple health dimensions of the population. Several findings in the literature show a positive effect of health on economic growth rates (FOGEL 1994; KNOWLES; OWEN 1995; BARRO 1996; BHARGAVA ET AL. 2001; BLOOM ET AL. 2001; SACHS 2001), although negative relationships have also been found (ZON; MUYSKEN 1997). According to Zon and Muysken (1997), negative effects may occur because health is a non-productive activity that competes with productive sectors of the economy for the allocation of resources.

Very few studies analyze this relationship for Brazil (MAYER et al. 2000; MORA; BARONA 2000; CERMENO 2000; MAYER 2000). In addition, their results are inconclusive and depend mainly on the health proxy used.

In this paper, besides analyzing the direct relationship between health conditions and economic growths, we also evaluate the indirect correlation that might be operating through education. Several different health measures were selected to take into account the different epidemiological and morbidity profiles observed among the states in Brazil. The measures include infant mortality rates, mortality rates due to perinatal complications at hospitals operating in the public healthcare system, and proportions of deaths from selected causes (vascular diseases, diabetes, cancer, AIDS and other communicable diseases, homicides and illdefined causes).

Our main findings show that health has a positive correlation with economic growth in Brazil and that lower infant mortality rates are closely correlated with higher rates of economic growth. The infant mortality rate is an overall measure of the average health level of a population and is quite sensitive to social policies. It is also a synthetic indicator widely used in the literature as a proxy for the average health status of the population. Nevertheless, it might be worthwhile to present the results using other health indicators as well, since health status is a multidimensional concept. Besides, the use of the hospital mortality rate due to perinatal complications allowed us to evaluate the relationship between health and economic growth over a longer period. The results were very similar for all health indicators. We found a significant and negative relationship for health indicators related to poverty, less access to health care services, and deaths from avoidable causes, such as communicable diseases and hospital mortality rates due to perinatal complications. In contrast, we found a positive and significant correlation between economic growth and the proportion death from diabetes and cancer. The high incidence of both diseases in Brazil (in contrast to communicable and parasitic diseases) is related to the aging of the population and correlates positively with better living conditions and access to local health services.

This paper contributes to the existing literature, as it provides evidence regarding the relationship between health and economic growth in Brazil, and this latter factor is fundamental for addressing the relationship between the persistence of poverty and inequalities, on the one hand, and the formation of human capital, on the other.

\section{Health and economic growth}

Health status can affect economic growth through at least three mechanisms: 1) directly, through the relationship between health status and individual earnings, 2) 
indirectly, through the effect of health on levels of education and, 3 ) through physical capital investments.

Poor health status causes considerable losses in individual income by decreasing labor productivity, the number of hours worked, and participation in the labor force (LUFT 1975; KASSOUF 1999; ALVES; ANDRADE 2003; MURRUGARRA; VALDIVIA 1999; IVASCHENKO 2003). These losses can affect the population's level of wealth and may result in lower levels of economic growth, therefore contributing to decreased social well-being.

The second mechanism operates through the effect of health on levels of education. On the one hand, there is a contemporaneous effect of health on educational level since individual health status affects individuals' school attendance and learning abilities (CUTLER; LRERASMUNEY 2006; SACHS 2001). On the other hand, the relationship between health and human capital stock can even be analyzed through the dynamic aspect of this relationship. The depreciation rate of human capital stock is directly related to the population's health status, and both are higher or lower depending on the technological level that contributes to improved medical interventions, access to healthcare services, demographic profiles, living and consumption habits, and criminality rates, and other factors. In societies with higher depreciation rates (for example, high mortality rates or lower life expectancy) the level of investments in education also tends to be lower, since the costs involved cannot be offset (FALCÃO; SOARES 2005; CUTLER; LRERAS-MUNEY 2006). From the individual perspective, lower health status decreases educational returns and thus affects family expenditures on education.

Another approach to this second mechanism emphasizes the relationship between mortality rates and fertility rates and their effects on educational levels. According to Sachs (2001), families with higher infant mortality rates tend also to show higher fertility rates, in order to compensate for the deaths of earlier children. In general, due to risk aversion, fertility rates can even surpass mortality rates and thus reduce the amount of resources available to parents for investing in further education. The relationships among health, education and economic growth may become even stronger by linking them to technological progress: the lower the level of human capital the less is spent on research (HOWITT 2005).

A third mechanism relating health to economic growth has to do with the effect of health on investments in physical capital. This pathway could operate either through the savings rate (since poor health conditions shorten people's life expectancies) or through health externalities, also known as diffuse externalities, since individual health levels also depend on the average health conditions in a society (SACHS 2001; ANDRADE; LISBOA 2000). This is the case of contagious diseases, including those that are avoidable through immunization and basic sanitation. Such externalities decrease investment levels, this effect being more evident in less developed countries, where health and poverty are closely related. Countries in Africa with high rates of AIDS are examples of how health externalities can undermine economic growth. Among other factors, business investments are very costly in these countries, partly because high rates of disease increase both the turnover of labor and rates of absenteeism and these factors raise training costs (SACHS 2001).

\section{Method}

\section{The model}

Our approach is based on an augmented Solow's model, based on the hypothesis that changes in the main parameters of the economy temporarily affect economic growth rates.

Let " $\mathrm{i}$ " refer to the states in Brazil, and let " $\mathrm{t}$ " represent years. The econometric model can thus be specified as follows (BARRO 1991):

$$
\begin{aligned}
\gamma_{i t}= & \beta_{1}+\beta_{2} y_{i t-1}+\beta_{3} \text { HEALTH }_{\text {it }-\mathrm{x}}+\Sigma_{\mathrm{t}} \beta_{\mathrm{t}} \text { year }_{\mathrm{t}}+ \\
& +\Sigma_{\mathrm{i}} \beta_{\mathrm{i}} \text { State }_{\mathrm{i}}+\Sigma_{\mathrm{j}} \beta_{\mathrm{j}} \mathrm{X}_{\mathrm{jit}-1}+\varepsilon_{\mathrm{it}}
\end{aligned}
$$

where: 
$\gamma_{\text {it }}=$ percentage growth rate of the real gross domestic product (GDP) per capita;

$\mathrm{y}_{\mathrm{it}-1}=$ initial real GDP per capita with a oneyear lag;

HEALTH $_{\text {it-x }}=$ average health condition of the population with lag of $x$ years;

Year $_{\mathrm{t}}=$ dummy variables defined for each year $t$, where $t$ extends from 1991 to 2000 (1995 being the reference year);

State $_{i}=$ dummy variables defined for each the 26 states, São Paulo being the reference category;

$\mathrm{X}_{\mathrm{jit}-1}=\mathrm{j}$ control variables defined for each state (i) and each year (t-1);

$\beta_{1}, \beta_{2}, \beta_{3}, \beta_{\mathrm{t}}, \beta_{\mathrm{s}}$, and $\beta_{\mathrm{j}}=$ estimated parameters of the model where $\beta_{1}$ is the constant term; $\varepsilon_{\mathrm{it}}=$ random shocks

\section{Measurements}

\section{- Economic growth rate}

The dependent variable is the growth rate of the real GDP per capita, expressed in percentage and measured in USD 1000 for 1990. The source of data was the official regional information published by the Brazilian Census Bureau (Instituto Brasileiro de Geografia e Estatística - IBGE), which provides the nominal GDP for each state (IBGE 2002a). In order to obtain the deflated GDP for each state (measured in USD 1000 of 1990), we estimated the series of the real Brazilian GDP. Next, we multiplied the states' share of nominal GDP per capita by the estimated real Brazilian GDP.

The analysis encompasses all 26 states between 1991 and 2000. The Federal District was excluded, as its economic activity is based on the public sector, a factor that makes it difficult to test the market mechanisms predicted by the economic growth models.

The period corresponding to the 1990s was chosen due to the availability of compatible and reliable data on health conditions for all states. Additionally, it was a period of remarkable structural changes in the Brazilian healthcare system, although the advances did not occur uniformly across the states. Even though this timeframe is not long, our data on it is enhanced by the country's regional diversity.
- Average health status of the population

We used several indicators to measure the average health status of the population. By using several different health measures, it was possible to assess the correlation between differences in morbidity and mortality profiles, on the one hand, and economic growth rates, on the other, as well as to test the robustness of the results. In the case of Brazil, only the mortality rates and inpatient care indicators referring to the public health system are available for longitudinal analyses. We use mortality rates from several different causes as proxies for the population's health status. The main constraint of inpatient care indicators is their relation to the supply of healthcare services. Thus, the behavior of these variables may be more closely associated with institutional realities than with the needs of the population.

The first indicator used is the infant mortality rate (IMR) for the period from 1990 to 1999 , and it refers to the ratio between the number of deaths among children under one year of age and the number of liveborn children. Our source is the official data published by the IBGE (2002b). The IMR is included in the model, assuming an inverse (non-linear) relationship with the economic growth rate. The relationship between the two variables is expected to be negative. i.e., the lower the IMR, the healthier the population and the greater the economic growth.

IMR levels vary greatly from one state to another, the highest rates occurring in the northeast of Brazil and the lowest in the south and southeast. In 1999, the IMR per 1,000 live births in the State of Alagoas was 65 , and it was near 50 in the states of Maranhão, Paraíba, and Pernambuco. All four of these states mentioned are located in the northeast. In contrast, the IMR was below 20 in Rio Grande do Sul (south), Santa Catarina (south) and São Paulo (southeast). The IMR fell in all states during the 1990s. The ratio between the lowest and highest values - which correspond, respectively, to the IMR at the end and at the beginning of each period - shows an average fall of about $33 \%$. The highest decreases occurred in 
Roraima (54\%) and the lowest in Amazonas and Amapá (28\%), all three of these latter states being located in northern Brazil.

Besides the IMR, we use the perinatal hospital mortality rate for the public healthcare system and the proportion of deaths from the groups of causes listed below, as classified according to the International Classification of Diseases (ICD), 9th and 10th revisions (covering the periods from 1991 to 1995 and from 1996 to 2001, respectively). Specifically, these groups of causes are: diseases of the circulatory system (ICD-9 and ICD-10, Chapter IX), diabetes mellitus (Code 250 of ICD-9 and Codes E10 to E15 of ICD-10), neoplasms (ICD-9 and ICD-10, Chapter II), communicable diseases (ICD-9 and ICD-10 Chapter I), AIDS (Code 279.1 of ICD-9 and Codes B20 to B24 of ICD-10), homicides (Codes from ICD-9 and ICD-10) and ill-defined causes (Chapter XVI of ICD-9 and Chapter XVIII of ICD-10). The data was obtained from the official Brazilian statistics on mortality (Sistema de Informações sobre Mortalidade - SIM), and Health Indicators and Basic Data 2005 (Indicadores e Dados Básicos de Saúde 2005), and both are available online (www.datasus.gov.br).

These causes of mortality reflect different morbidity profiles of the population. Diabetes, cardiovascular diseases and neoplasms are related to the growing numbers of aged persons in the populations of developed societies. In contrast, communicable diseases, including AIDS, and homicides are more prevalent in developing societies. III-defined causes are usually related to access to health care services. Brazil is a very heterogeneous country where both of the morbidity profiles mentioned above exist side by side.

The proportion of deaths from a number of different causes was included in the model, assuming a linear relationship, the measures being defined for the period from 1990 to 1999 . The hospital mortality rate due to perinatal complications was defined for the period extending from 1984 to 1993 . This variable was included in the model assuming an inverse relationship with economic growth. The hospital mortality rates for five states of northern Brazil (Rondônia,
Roraima, Acre, Amapá and Tocantins) is not available for the period from 1984 to 1990. We therefore adjusted a polynomial or exponential function, for the period from 1991 to 1997 in order to estimate the hospital mortality rate between 1984 and 1990 for these states.

\section{- Control variables}

Table 1 shows each control variable and the source and description of the data. These variables were chosen on the basis of empirical research, but constrained by data availability. The shares of industry and of services in the GDP were included to test whether the economies of scale have an impact on growth rate of the GDP per capita as predicted in the literature of the new economic geography (FUJITA; KRUGMAN; VENABLES 1999, FIGUEIRÊDO 2002). The inclusion of the variable of economic distance was an attempt to measure the transportation cost effect (FUJITA; KRUGMAN; VENABLES 1999; FIGUEIRÊDO 2002). According to the current economic geographic theory, transportation costs play a distributive role. If intermediate levels of transportation costs tend to contribute to the concentration of production in more developed economies, low transport costs might be expected to disperse production.

Additionally, we included per capita income $(y)$ at the beginning of each period in order to test for conditional convergence (convergence b), a set of dummy variables for each state (State of São Paulo being the reference category), and a set of dummy variables for each year (1995 being the reference category).

\section{Estimation procedures}

For the following reasons, we estimated equation (1) by using a panel procedure: a) to increase the number of observations and attenuate the problem of omitted variables; b) to control the model for effects of economic cycle effects by including dummy variables for each year.

The following exercises were carried out. First, we estimated the model including each health measure in order to verify its direct 
TABLE 1

Description of control variables

\begin{tabular}{ll}
\hline \multicolumn{1}{c}{ Control variable } & \multicolumn{1}{c}{ Description } \\
\hline $\begin{array}{l}\text { 1) Gini coefficient (based on per capita } \\
\text { household income ) }\end{array}$ & $\begin{array}{l}\text { A simple interpolation was determined for 1994. The PNAD does not take } \\
\text { the urban area into account for the states in northern Brazil. Based on the } \\
1991 \text { and } 2000 \text { Censuses, we estimated each variable for urban and rural } \\
\text { 2) Average number of years of study for } \\
\text { areas and then for rural areas alone. We obtained the ratio between the } \\
\text { variable estimated for the rural areas and the variable estimated for the two } \\
\text { areas for each census year. We then interpolated this ratio and applied the } \\
\text { value found in the corresponding variable, estimated on the basis of the } \\
\text { PNADs. }\end{array}$ \\
3) Proportion of WAP to total population
\end{tabular}

Data Source: PNADs for 1990, 1992, 1993, 1995-1999 and the 1991 and 2000 Censuses.
4) Urbanization rate (proportion of $\quad$ For the states in the northern region we performed a simple interpolation individuals living in urban areas) using the 1991 and 2000 Censuses.

Data Source: PNADs for 1990, 1992, 1993, 1995-1999 and the 1991 and 2000 Censuses.

5) Migration rate (refers to urban dwellers Immigrant: individual not having lived in the state during the previous five only) years but living there during the survey year. Emigrant: individual reporting place of residence for the previous five years, as he/she did not live in the state on that date. For 1994: simple interpolation.

Data Source: PNADs for 1990, 1992, 1993, 1995-1999 and the 1991 and 2000 Censuses.

6) Demographic density Data Source: Official Brazilian data

7) Fertility rate Estimated for 1991, 1995, 2000, 2005, 2010, 2015, and 2020. We used the 1991 fertility information for 1991-1994 and the 1995 information for 1995- 2000.

Data Source: Sawyer et al. (1999)

8) Variation rate of electric energy consumption (physical capital stock)

Data Source: Statistical Yearbook (several years)

9) Economic distance $D_{j}^{t}=\sum_{i} d_{i j}^{t} \frac{P I B_{i}^{t}}{P I B_{\text {total }}^{t}}$, where $d_{\mathrm{ij}}$ is the distance between the capital of State

$\mathrm{j}$ and the capital of State i. $D_{\mathrm{j}}$ is estimated for each state and for each year.

Data Source: Statistical Yearbook (2000) and regional data (1985-2000)

10) Share of industry in the GDP of each

State

Data Source: Statistical Yearbook (2000)

11) Share of services in the GDP of each state

association with economic growth. Second, we tested for the presence of any indirect correlation between health and economic growth by including an interaction term between the health indicator and educational level. The economic growth models were estimated by controlling separately for each health measure. The estimation procedure is of the stepwise-type, that is, when the model is estimated, the least statistically significant variable is removed so that only variables whose coefficients are different from zero with at least $10 \%$ of significance can be found (dummy variables indicative of both year and Brazilian state were maintained in all cases).

The relationship between economic growth and health is endogenous, that is, it is simultaneously determined by the model. Using instrumental variables, which are related to health status but not to the growth rate of the real GDP per capita, is a way to control for endogeneity. The variable itself - with a time lag in relation to the dependent variable - is commonly the instrument used in this kind of analysis. ${ }^{1}$ In order to take endogeneity into account, the

\footnotetext{
${ }^{1}$ Another possible instrument would be health supply indicators (e.g. beds per capita, physicians per capita, and sanitary conditions), but they correlated closely with per capita income.
} 
health measures used in this paper, as well as all control variables, were included with a one-year lag. For the hospital mortality rate consequent to perinatal complications in the public healthcare system, the time lag for the dependent variable was longer: a seven-year lag. Even though we recognize that there is a mutual causality between health and income and that our instrument does not fully control the endogeneity problem, we could interpret our results as at least a test of the significance of the relationship between health and economic growth in Brazil.

\section{Specification tests}

Three tests were applied: (1) the normality test, (2) the autocorrelation test and (3) the white heteroscedasticity test The test for normality of residuals considered both skewness and kurtosis tests, and the result led us to accept the hypothesis that the residuals are normally distributed at $1 \%$ significance. The model was corrected by the Prais-Winsten method and no significant discrepancies with the results estimated by the least squares method were found.

\section{Results}

\section{Health and economic growth}

Table 2 shows results for the model without including the interaction term between health status and educational level. The results are shown for health

TABLE 2

Results of the economic growth models with no interaction term between health and educational level (1)

\begin{tabular}{|c|c|c|c|c|c|c|c|c|c|c|c|c|}
\hline \multirow[t]{2}{*}{$\begin{array}{l}\text { Dependent variable: } \\
\text { economic growth } \\
\text { rate (\%) } \\
\text { Initial GDP }\end{array}$} & \multicolumn{2}{|c|}{$\begin{array}{l}\text { Inverse IMR } \\
\text { (complete } \\
\text { model) }\end{array}$} & \multicolumn{2}{|c|}{$\begin{array}{c}\text { Inverse IMR } \\
\text { (parsimonious) }\end{array}$} & \multicolumn{2}{|c|}{$\begin{array}{c}\text { Model } 3 \\
\text { Inverse } \\
\text { hospital } \\
\text { mortality rate } \\
\text { (parsimonious } \\
\text { model) }\end{array}$} & \multicolumn{2}{|c|}{$\begin{array}{l}\text { Model } 4 \\
\text { Proportion of } \\
\text { deaths from } \\
\text { cancer } \\
\text { (parsimonious } \\
\text { model) }\end{array}$} & \multicolumn{2}{|c|}{$\begin{array}{c}\text { Model } 5 \\
\text { Proportion of } \\
\text { deaths from } \\
\text { communicable } \\
\text { diseases } \\
\text { (parsimonious } \\
\text { model) }\end{array}$} & \multicolumn{2}{|c|}{$\begin{array}{c}\text { Model } 6 \\
\text { Proportion of } \\
\text { deaths from } \\
\text { diabetes } \\
\text { (parsimonious } \\
\text { model) }\end{array}$} \\
\hline & -23.22 & $\star \star \star *$ & -21.46 & $\star \star \star *$ & -22.88 & $\star \star \star *$ & -22.37 & $\star \star *$ & -24.12 & $\star \star \star *$ & -22.49 & $\star \star * *$ \\
\hline $\begin{array}{l}\text { Variation rate of } \\
\text { electric energy costs }\end{array}$ & 2.27 & * & & & 2.67 & * & 2.37 & * & & & 2.57 & * \\
\hline Fertility rate & 5.37 & Ns & & & 8.53 & ** & 7.96 & ** & 10.86 & $\star \star \star$ & 8.68 & $\star \star \star$ \\
\hline Gini coefficient & -2.51 & Ns & & & & & & & & & & \\
\hline $\begin{array}{l}\text { WAP proportion } \\
\text { in relation to total } \\
\text { population }\end{array}$ & 69.22 & Ns & & & & & & & & & & \\
\hline Educational level & 7.24 & $\star \star$ & 7.54 & $\star \star \star$ & 7.53 & ** & 7.64 & ** & 7.12 & ** & 7.84 & ** \\
\hline Urbanization rate & -0.41 & $\star \star$ & -0.43 & ** & -0.37 & ** & -0.35 & $\star \star$ & -0.33 & * & -0.39 & ** \\
\hline Population density & 0.01 & Ns & & & & & & & & & & \\
\hline Economic distance & -0.13 & $\star \star$ & -0.11 & * & -0.11 & * * & -0.09 & * & -0.11 & ** & -0.09 & * \\
\hline $\begin{array}{l}\text { Migration rate (urban } \\
\text { dwellers) }\end{array}$ & -0.22 & Ns & & & -0.46 & ** & -0.43 & ** & & & -0.44 & ** \\
\hline $\begin{array}{l}\text { Share of industry in } \\
\text { state GDP }\end{array}$ & -0.14 & Ns & & & & & & & & & & \\
\hline $\begin{array}{l}\text { Share of services in } \\
\text { state GDP }\end{array}$ & -0.21 & Ns & & & & & & & & & & \\
\hline HEALTH & 903.31 & $\star \star \star *$ & 1022.68 & $\star \star \star$ & 0.21 & $\star \star \star *$ & 0.96 & * & -0.76 & ** & 2.36 & * \\
\hline Constant F & 104.31 & * & 117.74 & $\star \star \star$ & 140.21 & $\star \star \star$ & 116.81 & $\star \star \star *$ & 151.01 & $\star \star \star$ & 125.73 & $\star \star \star *$ \\
\hline & 5.17 & & 5.29 & & 6.14 & & 5.75 & & 5.85 & & 5.73 & \\
\hline Prob $>F$ & 0.0000 & & 0.0000 & & 0.0000 & & 0.0000 & & 0.0000 & & 0.0000 & \\
\hline $\mathrm{R} 2$ & 0.5464 & & 0.5214 & & 0.5224 & & 0.5207 & & 0.5146 & & 0.5219 & \\
\hline Root MSE & 5.21 & & 5.26 & & 5.29 & & 5.30 & & 5.31 & & 5.30 & \\
\hline $\mathrm{N}$ & 260 & & 260 & & 260 & & 260 & & 260 & & 260 & \\
\hline
\end{tabular}

Source: IBGE, 2002a. IBGE, 2002b. Indicadores e Dados Básicos de Saúde, 2005. IBGE, PNAD 1990, 1992, 1993, 1995-1999. IBGE, Censos Demográficos 1991 e 2000. Sawyer et al, 1999. Statistical Yearbook, 1990- 2000. Regional accounts, $1990-2000$.

(1) The models of economic growth were estimated controlling for dummy variables representing each state. (Reference category is São Paulo) and each year (varying between 1991 and 2000).

Note: ns: not significant, * significant at $10 \%,{ }^{* \star}$ significant at $5 \%,{ }^{\star \star *}$ significant at $1 \%$. 
indicators whose correlation with economic growth was statistically significant. These indicators are: 1) the inverse of the infant mortality rate (IMR), 2) the inverse of the hospital mortality rate due to perinatal complications and, 3) proportion of deaths from cancer, communicable diseases and diabetes. The results are quite robust and carry the expected sign. In addition, there is a positive and significant correlation between health and growth. The correlation between economic growth and proportion of deaths from vascular diseases, AIDS, homicides and ill-defined causes were not significant (results not shown here).

The second and third columns of Table 2 show the results of the complete and the parsimonious models, respectively. Both models consider the inverse of the infant mortality rate as proxies for health. The four columns on the right show the results for the parsimonious model, which considers as a health proxy the inverse of hospital mortality rate due to perinatal complications, and the proportion of deaths from cancer, communicable diseases and diabetes.

\section{- Infant mortality rate and economic growth}

The results of the model that considers the inverse of IMR as a health proxy are quite similar and, in most cases, the sign is as expected. The main variables correlated with economic growth rates of the different states in Brazil are the initial GDP per capita, human capital level (the IMR and educational level), economic distance, and urbanization rate. Controlling for steady state level, the lower the initial output level, the higher the economic growth rate. The effect of the average education of the workingage population is also positive, while the economic distance and urbanization rates are negatively correlated with economic growth. This negative relationship between economic distance and economic growth indicates that the states that are next to more economically prosperous economies experienced higher annual growth rates of their real GDP per capita during the 1990s. Regarding the fertility rate, we found a positive but non-significant effect.
The estimated coefficient for the inverse of IMR is positive and highly significant, indicating that better health conditions are related to higher rates of economic growth. For example, between 1990 and 1999, the infant mortality rate in the State of Alagoas (northeast) fell from 100.1 to 65.4 deaths per 1,000 live births, which means an increase in the inverse of the IMR by 0.0053 units. Ceteris paribus, this decrease in IMR is associated with an economic growth rate that is $5.43 \%$ higher.

Using the coefficients estimated by the parsimonious model, which considers the inverse of IMR as a health proxy (third column in Table 2), we can obtain the predicted average annual economic growth rate. Figure 1 shows these results by the infant mortality rates as observed in all states between 1990 and 1999 when all control variables are considered at their overall mean values. According to Figure 1, the lowest IMR (16 deaths per 1000 live births) would be associated with a positive annual economic growth rate of $30 \%$, whereas the highest IMR (100 deaths per 1000 live births) would be associated with a negative annual economic growth rate of around $20 \%$. We can also see that whenever the IMR is above 32 per 1000, the annual economic growth rates are negative (considering all control variables at their mean values).

\section{- $\quad$ Other health proxies and economic growth}

The four columns on the right in Table 2 present the results for other health indicators. All estimations evidence a positive association between health and economic growth in Brazil. Coefficients for the inverse of hospital mortality rate due to perinatal complications and for the proportion of deaths from cancer and diabetes are positive and significant. In contrast and as expected, the proportion of deaths from communicable diseases is found to be negatively and significantly correlated with economic growth.

The effects of the control variables were quite similar to those found when the inverse of IMR was considered a health proxy. As in the previous model, the correlation for the 
FIGURE 1

Predicted average of the annual economic growth rates measured in percentages as per levels of the infant mortality rate seen in all states in Brazil from 1991 to 2000

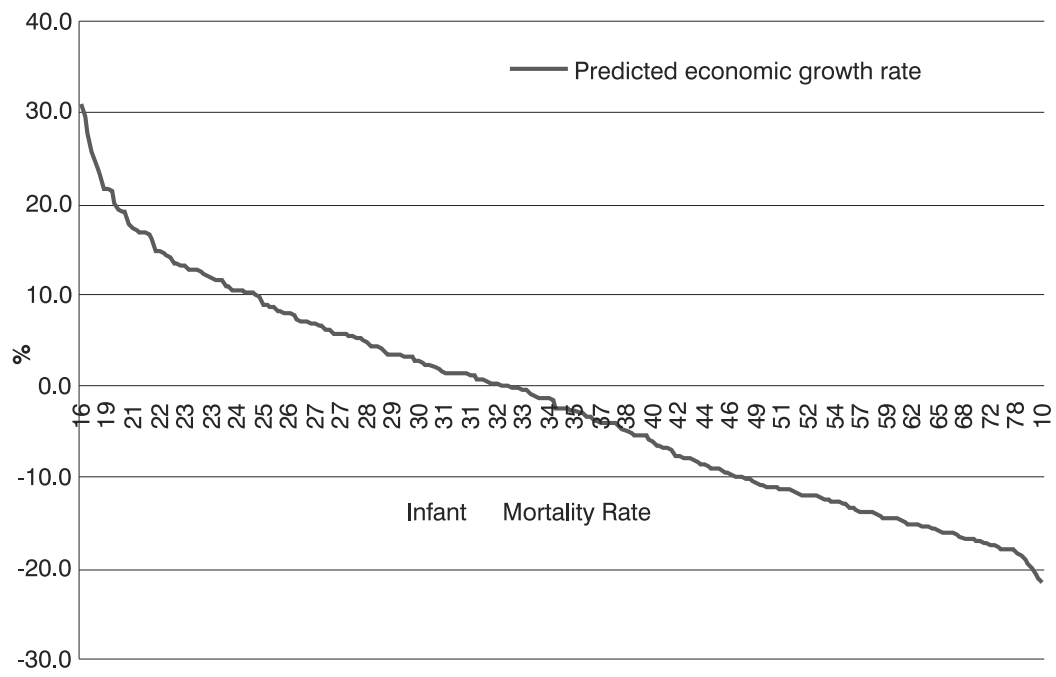

Source: IBGE, 2002a. IBGE, 2002b. Indicadores e Dados Básicos de Saúde, 2005. IBGE, PNAD 1990, 1992, 1993, 1995-1999. IBGE, Censos Demográficos 1991 e 2000. Sawyer et al, 1999. Statistical Yearbook, 1990- 2000. Regional accounts, 1990-2000

fertility rate is positive, but now presents a significant coefficient. According to this result, higher fertility rates seem to contribute to economic growth. From a macroeconomic perspective, the fertility rate may be measuring the higher potential of economic growth in societies whose demographic transition is in its initial stages. Its effect can be compared to the effect of initial income per capita in the economic growth model.

Health, educational level and economic growth

Table 3 shows results for the model that includes the interaction term between population health status and average educational level. This analysis measures the association between health status and economic growth that is mediated by level of education. The results are shown only for the models whose interaction term between health and level of education was statistically significant. This is the case of the models that consider proportion of deaths "from diabetes and communicable diseases" as health proxies. The interaction term between the average educational level and the other health indicators was not significant.

Analysis of the results of the two models shown in Table 3 indicates that, after the interaction term has been controlled, the coefficient that represents the direct association of health with economic growth became non-significant, whereas the interaction term is negative and significant for the proportion of deaths from communicable diseases and positive and significant for proportion of deaths from diabetes. These results suggest that a population's health can be indirectly correlated to economic growth through the relation of health with educational levels.

For instance, when we consider the proportion of deaths from communicable diseases the net effect of education is given by:

(9.18-0.17x prop. deaths from communicable diseases) $x$ education.

This relation shows that education positively affects the growth rate when the proportion of deaths from communicable diseases is below 54. For all states in Brazil, this proportion was lower than 54 throughout the $1990 \mathrm{~s}$, having varied from 4.61 to 21.2 . If 
TABLE 3

Results of the economic growth models, controlling for the interaction term between health and educational level

\begin{tabular}{|c|c|c|c|c|}
\hline \multirow{3}{*}{$\begin{array}{l}\begin{array}{c}\text { Dependent variable: economic } \\
\text { growth rate (\%) }\end{array} \\
\text { Initial GDP }\end{array}$} & \multicolumn{4}{|c|}{ Results of the model controlling for: } \\
\hline & \multicolumn{2}{|c|}{$\begin{array}{l}\text { Proportion of deaths from } \\
\text { communicable diseases }\end{array}$} & \multicolumn{2}{|c|}{$\begin{array}{l}\text { Proportion of deaths } \\
\text { from diabetes }\end{array}$} \\
\hline & -24.22 & $* \star *$ & -22.51 & $\star \star \star *$ \\
\hline Variation rate of electric energy & & & 2.48 & * \\
\hline Fertility rate & 11.06 & *** & 7.98 & ** \\
\hline Educational level & 9.18 & *** & 6.98 & ** \\
\hline Urbanization rate & -0.36 & ** & -0.39 & ** \\
\hline Economic distance & -0.11 & ** & -0.10 & * \\
\hline Migration rate (urban residents) & & & -0.43 & ** \\
\hline HEALTH*EDUC & -0.17 & ** & 0.53 & ** \\
\hline Constant & 148.48 & $\star \star \star *$ & 133.40 & $\star * *$ \\
\hline$F$ & 5.99 & & 5.82 & \\
\hline Prob $>F$ & 0.0000 & & 0.0000 & \\
\hline $\mathrm{R} 2$ & 0.5179 & & 0.5259 & \\
\hline Root MSE & 5.29 & & 5.27 & \\
\hline Não & 260 & & 260 & \\
\hline
\end{tabular}

Source: IBGE, 2002a. IBGE, 2002b. Indicadores e Dados Básicos de Saúde, 2005. IBGE, PNAD 1990, 1992, 1993, 1995-1999. IBGE, Censos Demográficos 1991 e 2000. Sawyer et al, 1999. Statistical Yearbook, 1990- 2000. Regional accounts, 1990-2000

(1) The economic growth models were estimated by controlling for dummy variables representing each Brazilian state (reference category is São Paulo) and each year (varying between 1991 and 2000).

Note: ns: not significant, * significant at $10 \%,{ }^{* *}$ significant at $5 \%,{ }^{* \star *}$ significant at $1 \%$.

the proportion of deaths from communicable diseases is very high, individuals will probably have lower life expectancies, and this fact could affect the country's investments in human capital. Thus, higher educational levels favored the growth rate of the real GDP per capita during the period. However, the net effect of education was lower than its gross effect (estimated without considering the interaction term between health and levels of education) due to the indirect relationship between the proportion of deaths from communicable diseases and economic growth.

The results estimated for the proportion of deaths from diabetes show a different pattern, as can be seen in the positive and significant coefficient estimated for the interaction term. In this case the effect of education is always positive, and a higher proportion of deaths from diabetes increases its effect even further.

\section{Discussion}

The objective of this paper is to analyze the relationship between health status and the growth of per capita income among the states in Brazil during the 1990s. We considered both direct and indirect mechanisms. A direct relationship can be determined if the effects of health on individual earnings are reproduced on the macroeconomic level. An indirect relationship can be observed if health affects economic growth through the effect of health on level of education. Good health status contributes to a reduction in the depreciation rate of human capital and to increases in educational stock. A positive indirect correlation between health and economic growth is therefore expected, since heavier investments in education and other forms of human capital improve a population's average productivity.

Our main findings show that health in Brazil correlates positively with economic growth. We found that decreases in the infant mortality rate are closely associated with higher rates of economic growth. Among the Brazilian states during the 1990s, the infant mortality rate fells an average of approximately $36 \%$ (from 50.45 deaths per 1000 live births in 1990 to 32.40 in 1999). According to our results, this reduction would be associated with the $11 \%$ increase 
in the average rate of economic growth ceteris paribus. The highest fall in the infant mortality rate between 1990 and 1999 was observed in the north and northeast of the country. Examples would be the states of Roraima (north), Piauí (northeast), and Ceará (northeast), with decreases of $54 \%, 40 \%$ and $42 \%$, respectively. Ceteris paribus, these decreases are associated with economic growth rates of $28 \%, 11 \%$ and $10 \%$ higher, respectively. These percentages are significant compared to the economic growth rates observed in the 1990 s among the Brazilian states.

Infant mortality rate is an overall measure of the average health level of a population and is quite sensitive to social policies. It reflects the health status of live born children and that of their parents, since it is associated both with health policies that provide preventive actions for the population, and the health status of parents, especially in regard to nutrition, living habits, and information on health. The infant mortality rate provides a certain amount of information on access to health care services. In this regard, one should keep in mind that most of the deaths of children under one year of age result from avoidable causes related to socioeconomic characteristics in their environments and the amount of preventive care received.

We tested the infant mortality rate as well as other variables as proxies for the population's average health status. Although the infant mortality rate is a synthetic indicator widely used in the literature as a proxy for the average health status of the population, it would also seem important to present results based on other health indicators, since health status is a multidimensional concept.

The results estimated for proportion of deaths from selected causes and hospital mortality rates due to perinatal complications were very similar to those found for infant mortality rates, and this confirms the reliability of infant mortality rates as an overall measure of the health of the population. We found a significant and negative relationship for health indicators that are related to poverty, such as less access to health care services and deaths from avoidable causes, including communicable diseases, and hospital mortality rate due to perinatal complications. On the other hand, we found a positive and significant association of the proportion of deaths from diabetes and cancer with economic growth. In Brazil, the higher incidence of these illnesses (compared to communicable and parasitic diseases) is related to the aging population and positively associated to better living conditions and access to local health services.

The indirect relationship between health and economic growth mediated by education is found significant only when the proportion of deaths from communicable diseases and from diabetes are considered health proxies. Increases in the average number of years of schooling of the working-age population contribute to higher economic growth. During the 1990s the average educational gain was 1.12 years, which contributed to an $8 \%$ increase in the growth rate (ceteris paribus). During this period the states showing the highest educational level gains were Acre (1.6), Tocantins (1.51), and Roraima (1.5) (all located in the northern region), and the effect of such gains on the economic growth rate was around $11 \%$. When the interaction term between proportion of deaths from communicable diseases and educational level is included, it becomes clear that the higher proportion of deaths from communicable diseases slightly reduces the positive effect of education on economic growth. Also, the direct relationship between this health proxy and economic growth becomes non-significant. A positive correlation between the interaction term and economic growth is found when the proportion of deaths from diabetes is taken into account. As noted above, this variable might be reflecting better health status of the population, since a relatively high prevalence of chronic diseases, such as diabetes, is related to increased numbers of aging persons in the population and to more developed regions.

Our results differ from those published by Knowles and Owen (1995). According to their study, the effect of education on economic growth becomes non-significant after controlling for the effect of health in 
this model. In the present study, we found a positive and significant correlation between economic growth and level of education even after including the health proxies in the model. In addition, the relationship with economic growth seems to be mediated by education for some health measures.

The main caveat of this paper is its short time horizon. We recognize that the period used is insufficient for obtaining more robust considerations concerning the dynamics of economic growth. However, since we are dealing with a panel analysis,

\section{References}

ALVES, L. F. E.; ANDRADE, M. V. Impactos da saúde nos rendimentos individuais no Brasil. Revista de Economia Aplicada, São Paulo, 2003.

ALVES, L. F.; ANDRADE, M. V.; MACEDO, P. B. R. M. Health and labor market in Brazil. 2003. Mimeographed.

ANAND, S.; RAVALLION, M. Human development in poor countries: on the role of private incomes and public services. Journal of Economic Perspectives, 7, 1993.

BARRO, R. Economic growth in a cross section of countries. Quarterly Journal of Economic, 196 (2/May), p. 407-443, 1991.

Health and economic growth.

Convocatoria para propuestas de investigación sobre Inversión en Salud y Crecimiento Económico de la Organización Panamericana de la Salud, Annex I, 1996.

BARRO, R.J.; LEE, J, W. International comparisons of educational attainment. Journal of Monetary Economics, v. 32, p. 363-394, 1993.

BHARGAVA, A.; JAMISON, D. T.; LAU, L. J.; MURRAY, C. J. L. Modeling the effects of health on economic growth. Journal of Health Economics, n. 20, p. 423-440, 2001.

BLOOM, D. E.; CANNING, D.; SEVILLA, J. The effect of health on economic growth: theory and evidence. Cambridge: National Bureau of Economic Research, 2001 (Working paper, 8587). we believe that such limitation is at least partially offset by the heterogeneity among the Brazilian states in terms of their stages of development and epidemiological profiles. The correlation between health and economic growth described in this paper may be underestimated, since we are unable to analyze long-term effects of poor health conditions on economic growth. The main constraint in this area is the unavailability of reliable morbidity and mortality measures for the Brazilian states over longer periods.

CERMENO, R. Education, health and growth: panel regressions for Latin America, Brazil, Colombia and México. In: MAYER, D.; MORA, H.; CERMEÑO, R.; BARONA, A.B.; DURYEAU, S. (Eds.). Health, growth and income distribution in Latin America and the Caribbean: a study of determinants and regional and local behavior. Washington, DC.: Pan-American Health Organization, 2000 (Research in Public Health Technical Papers, 18).

CUTLER, D. M.; LLERAS-MUNEY, A. Education and health: evaluating theories and evidence, July 2006 (NBER Working Paper, n. W12352).

FALCÃO, B.L.S; SOARES, R.R. The demographic transition and the sexual division of labor. Stanford: Stanford Institute on International Studies, Center on Democracy, Development, and the Rule of Law. CDDRL, 2005 (Working paper, 50).

FIGUEIRÊDO, L. de. The new economic geography and regional growth in Brazil and India. Thesis (Doctor of Philosophy). University of Nottingham, 2002.

FOGEL, R. W. Economic growth, population theory and physiology: the bearing of longterm process on the making of economic policy. American Economic Review, v. 84, n.3, p. 369-95, 1994.

FUJITA, M.; KRUGMAN, P.; VENABLES, A. J. The spatial economy: cities, regions, and international trade. Cambridge, MIT: The MIT Press, 1999. 
FUNDAÇÃO GETÚLIO VARGAS - FGV. Conjuntura Econômica, 2000.

HOWITT, P. Health, human capital, and economic growth: a schumpeterian perspective. In: LÓPEZ-CASANOVAS, G.; RIVERA, B.; CURRAIS, L. (Eds.). Health and economic growth. Cambridge: The Mit Press, 2005.

IDB. Indicadores e dados básicos Brasil. Ministério da Saúde, Datasus, 2005. Available in: <http://tabnet.datasus.gov.br/ cgi/idb 2005/matriz.htm>. Access in: 18 September 2008.

IBGE - Instituto Brasileiro de Geografia e Estatística. Anuário Estatístico do Brasil. Rio de janeiro, vários anos. Janeiro, 1991

Censo Demográfico. Rio de

Censo Demográfico. Rio de Janeiro, 2000.

. Diretoria de Pesquisas, Departamento de Contas Nacionais. Contas Regionais do Brasil 1985- 2000. Rio de Janeiro, 2002a (CD-ROM).

\section{Pesquisa Nacional por Amostra \\ de Domicílio - PNAD. Rio de Janeiro, vários anos.}

Censo Demográfico 2000: fecundidade e mortalidade infantil. Resultados preliminares da amostra. IBGE. Rio de Janeiro, 2002b.

KASSOUF, A. L. Rendimentos perdidos por trabalhadores em condições inadequadas de saúde. Economia Aplicada, São Paulo, v. 3, n. 2, p. 239-262, 1999.

KNOWLES, S.; OWEN, P. D. Health capital and cross-country variation in income per capita in the Mankiw Romer Weil-model. Economics-Letters, v. 48, n.1, p. 99-106, April 1995.

LUCAS, R.E. On the mechanics of economic development. Journal of Monetary Economics, 22, p. 3-42, 1988.

MANKIW, N. G.; ROMER, D.; WEIL, D. A Contribution to the empirics of economic growth. Quarterly Journal of Economics, p. 407-437, May 1992.
MAYER, D. Health in the economic and demographic transition of Brazil, 1980-1995. In: MAYER, D.; MORA, H.; CERMEÑO, R.; BARONA, A.B.; DURYEAU, S. (Eds.). Health, growth and income distribution in Latin America and the Caribbean: a study of determinants and regional and local behavior. Washington, DC.: Pan-American Health Organization, 2000 (Research in Public Health Technical Papers, 18).

MAYER, D.; MORA, H.; CERMEÑO, R.; BARONA, A.B.; DURYEAU, S. (Eds.). Health, growth and income distribution in Latin America and the Caribbean: a study of determinants and regional and local behavior. Washington, DC.: Pan-American Health Organization, 2000 (Research in Public Health Technical Papers, 18)

MORA, H.; BARONA, A. B. Health in the economic growth of Latin América. In: MAYER, D.; MORA, H.; CERMEÑO, R.; BARONA, A.B.; DURYEAU, S. (Eds). Health, growth and income distribution in Latin America and the Caribbean: a study of determinants and regional and local behavior. Washington, DC.: Pan-American Health Organization, 2000 (Research in Public Health Technical Papers, 18).

PNUD - Programa das Nações Unidas para o Desenvolvimento. Relatório do desenvolvimento humano 2002: aprofundar a democracia num mundo fragmentado. New York, 2002.

ROMER, P. M. Increasing returns and longrun growth. Journal of Political Economy, v. 94, n.5, p. 1002-37, October 1986.

SACHS, J. D. Macroeconomics and health: investing in health for economic development. Report of the Commission on Macroeconomics and Health. World Health Organization, 2001.

SAWYER, O. D.; WONG, L. R.; CARVALHO, J. A. M.; FÍGOLI, M.; ANDRADE, F. C. D.; BARBIERI, A. F.; TAVARES C. R. G. Projeção populacional, por sexo e grupos qüinqüenais, das Unidades da Federação, Brasil, 1990-2020. Belo Horizonte: CedeplarUFMG, 1999. Mimeografado. 
SOLOW, R.M. A Contribution to the theory of economic growth. Quarterly Journal of Economics, 70, p. 65-94, 1956.

THOMAS, D.; STRAUSS, J. Health and wages: evidence on men and women in urban Brazil. Journal of Econometrics, 77, 1997.

UNITED NATIONS. Department of Economic and Social Affairs, Population Division.
World population prospects: the 2006 revision. CD-ROM Edition - Extended Dataset in Excel and ASCII formats (United Nations publication, Sales n. E.07.XIII.7), 2007.

ZON, A. VAN; MUYSKEN, J. Health, education and endogenous growth. Paper presented at the annual conference of the International Institute of Public Finance, Kyoto, 1997. MERIT Research Memorandum, n. 97-009.

\section{Resumo}

Saúde e crescimento econômico entre 1991 e 2000: uma análise empírica para os Estados brasileiros

Estado de saúde pode afetar o crescimento econômico por meio de pelo menos três mecanismos: diretamente, através da relação entre estado de saúde e rendimentos individuais; indiretamente, pelo efeito da saúde sobre níveis educacionais; e por meio de investimentos em capital físico. Condições precárias de saúde podem causar perdas consideráveis de renda individual, ao reduzir a produtividade do trabalho, o número de horas trabalhadas e a participação na força de trabalho, o que pode afetar o nível médio de riqueza de uma população, além de contribuir para a redução do nível de bem-estar social. O principal objetivo desse estudo é avaliar a relação entre saúde e crescimento econômico nos Estados brasileiros. A análise abrange o período entre 1991 e 2000. Para considerar diferentes perfis epidemiológicos e de morbidade observados entre os Estados, várias medidas de saúde foram selecionadas, tais como taxa de mortalidade infantil, taxa de mortalidade hospitalar devido a complicações perinatais e proporção de mortes por causas selecionadas (doenças cardiovasculares, diabetes, câncer, Aids e outras doenças transmissíveis, homicídios e causas mal-definidas). Os principais resultados mostram que, no Brasil, estado de saúde está positivamente correlacionado com crescimento econômico, havendo uma relação negativa e significativa entre crescimento econômico e indicadores de saúde que estão associados com maiores níveis de pobreza, pior acesso aos cuidados de saúde e mortes por causas evitáveis, tais como doenças transmissíveis e taxas de mortalidade devido a complicações perinatais. Por outro lado, verificou-se uma relação positiva e significativa entre crescimento econômico e proporção de mortes por diabetes e câncer.

Palavras-chave: Saúde. Crescimento econômico. Capital humano.

\section{Resumen}

Salud y crecimiento económico entre 1991 y 2000: un análisis empírico para los estados brasileños

El estado de salud puede afectar el crecimiento económico mediante por lo menos tres mecanismos: directamente, a través de la relación entre estado de salud y rendimientos individuales; indirectamente, por el efecto de la salud sobre niveles educacionales; y por medio de inversiones en capital físico. Las condiciones precarias de salud pueden causar pérdidas considerables de renta individual, al reducir la productividad del trabajo, el número de horas trabajadas y la participación en la fuerza de trabajo, lo que puede afectar el nivel medio de riqueza de una población, además de contribuir a la reducción del nivel de bienestar social. El 
principal objetivo de este estudio es evaluar la relación entre salud y crecimiento económico en los estados brasileños. El análisis abarca el período entre 1991 y 2000 . Para considerar diferentes perfiles epidemiológicos y de morbilidad observados entre los estados, se seleccionaron varias medidas de salud, algunas como: tasa de mortalidad infantil, tasa de mortalidad hospitalaria, debido a complicaciones perinatales, y la proporción de muertes por las siguientes causas seleccionadas: enfermedades cardiovasculares, diabetes, cáncer, Sida y otras enfermedades transmisibles, homicidios y causas mal-definidas). Los principales resultados muestran que, en Brasil, el estado de salud está positivamente correlacionado con el crecimiento económico, existiendo una relación negativa y significativa entre crecimiento económico e indicadores de salud que están asociados a mayores niveles de pobreza, peor acceso a los cuidados de salud y muertes por causas evitables, algunas como enfermedades transmisibles y tasas de mortalidad, debido a complicaciones perinatales. Por otro lado, se verificó una relación positiva y significativa entre crecimiento económico y proporción de muertes por diabetes y cáncer.

Palabras-clave: Salud. Crecimiento económico. Capital humano.

Recebido para publicação em 13/01/2010

Aceito para publicação em 05/06/2010 